\title{
Conservative and surgical management of foot and ankle sporting injuries in the weekend warrior
}

Harvinder S Bedi

From Australasian Podiatry Council Conference 2011

Melbourne, Australia. 26-29 April 2011

A clinical based review of the injuries that are regularly suffered by Joan and John Average is presented. Common presentations of conditions such as lateral ligament tears, talar osteochondral lesions, syndesmotic injuries and $5^{\text {th }}$ Metatarsal fractures are discussed along with the management and prognosis of these problems. Questions are answered including how does it occur; what should I do about it; what can somebody else do about it and what occurs in the future?

Published: 20 May 2011

doi:10.1186/1757-1146-4-S1-I1

Cite this article as: Bedi: Conservative and surgical management of foot and ankle sporting injuries in the weekend warrior. Journal of Foot and Ankle Research 2011 4(Suppl 1):11.

Submit your next manuscript to BioMed Central and take full advantage of:

- Convenient online submission

- Thorough peer review

- No space constraints or color figure charges

- Immediate publication on acceptance

- Inclusion in PubMed, CAS, Scopus and Google Scholar

- Research which is freely available for redistribution 